University of Nebraska - Lincoln

DigitalCommons@University of Nebraska - Lincoln

\title{
Priority Effects Among Young-of-the-year Fish: Reduced Growth of Bluegill Sunfish (Lepomis macrochirus) Caused by Yellow Perch (Perca flavescens)?
}

\author{
Mark A. Kaemingk \\ University of Nebraska - Lincoln, mkaemingk2@unl.edu \\ Jeffrey C. Jolley \\ David W. Willis \\ Steven R. Chipps
}

Follow this and additional works at: https://digitalcommons.unl.edu/natrespapers

Part of the Natural Resources and Conservation Commons, Natural Resources Management and Policy Commons, and the Other Environmental Sciences Commons

Kaemingk, Mark A.; Jolley, Jeffrey C.; Willis, David W.; and Chipps, Steven R., "Priority Effects Among Young-of-the-year Fish: Reduced Growth of Bluegill Sunfish (Lepomis macrochirus) Caused by Yellow Perch (Perca flavescens)?" (2012). Papers in Natural Resources. 708.

https://digitalcommons.unl.edu/natrespapers/708

This Article is brought to you for free and open access by the Natural Resources, School of at DigitalCommons@University of Nebraska - Lincoln. It has been accepted for inclusion in Papers in Natural Resources by an authorized administrator of DigitalCommons@University of Nebraska - Lincoln. 


\title{
Priority effects among young-of-the-year fish: reduced growth of bluegill sunfish (Lepomis macrochirus) caused by yellow perch (Perca flavescens)?
}

\author{
MARK A. KAEMINGK*, JEFFREY C. JOLLEY ${ }^{\dagger}$, DAVID W. WILLIS* AND STEVEN R. CHIPPS \\ *Department of Natural Resource Management, South Dakota State University, Brookings, SD, U.S.A. \\ ${ }^{+}$United States Fish and Wildlife Service, Columbia River Fisheries Program Office, Vancouver, WA, U.S.A. \\ ${ }^{\ddagger}$ United States Geological Survey, South Dakota Cooperative Fish and Wildlife Research Unit, South Dakota State University, Brookings, \\ SD, U.S.A.
}

\section{SUMMARY}

1. When available, Daphnia spp. are often preferred by age-0 yellow perch and bluegill sunfish because of energetic profitability. We hypothesised that predation by age- 0 yellow perch could lead to a midsummer decline (MSD) of Daphnia spp. and that priority effects may favour yellow perch because they hatch before bluegill, allowing them to capitalise on Daphnia spp. prior to bluegill emergence.

2. Data were collected from 2004 to 2010 in Pelican Lake, Nebraska, U.S.A. The lake experienced a prolonged MSD in all but 1 year (2005), generally occurring within the first 2 weeks of June except in 2008 and 2010 when it occurred at the end of June. MSD timing is not solely related to seasonal patterns of age-0 yellow perch consumption. Nevertheless, when Daphnia spp. biomass was low during 2004 and 2006-2010 ( $<4$ mg wet weight $\mathrm{L}^{-1}$ ), predation by age-0 yellow perch seems to have suppressed Daphnia spp. biomass (i.e. $<1.0 \mathrm{mg}$ wet weight $\mathrm{L}^{-1}$ ). The exception was 2005 when age- 0 yellow perch were absent.

3. Growth of age-0 bluegill was significantly faster in 2005, when Daphnia spp. were available in greater densities $\left(>4 \mathrm{mg}\right.$ wet weight $\mathrm{L}^{-1}$ ) compared with the other years $(<0.2 \mathrm{mg}$ wet weight $\mathrm{L}^{-1}$ ).

4. We conclude that age-0 yellow perch are capable of reducing Daphnia biomass prior to the arrival of age-0 bluegill, ultimately slowing bluegill growth. Thus, priority effects favour age-0 yellow perch when competing with age-0 bluegill for Daphnia. However, these effects may be minimised if there is a shorter time between hatching of the two species, higher Daphnia spp. densities or lower age- 0 yellow perch densities.

Keywords: bluegill, competition, Daphnia, priority effects, yellow perch

\section{Introduction}

The order of arrival and abundance of two species can influence interspecific competition for available resources, affecting growth or survival of either or both species (Wilbur \& Alford, 1985; Fincke, 1999; Ohashi, Leslie \& Thomson, 2008; Geange \& Stier, 2009). The term 'priority effect' relates to a scenario where one species may ultimately affect another species, but the degree of influence depends on the sequence (order of arrival) and timing of arrival of individuals into the community (Lawler \& Morin, 1993). Priority effects usually involve competition for available habitat, but can also refer to competition for prey resources (Lawler \& Morin, 1993; Hall, 2004; Stevens, 2009). Most commonly, priority effects are driven by breeding phenologies. In addition to priority effects, 'seasonal effects' can also be an important component when describing phenology and interspecific competition between two species. Environmental conditions often drive seasonal patterns in resource availability

Correspondence: Mark A. Kaemingk, Department of Natural Resource Management, South Dakota State University, Brookings, SD 57007, U.S.A. E-mail: mark.kaemingk@sdstate.edu 
and can have an important influence on interspecific interactions (Lawler \& Morin, 1993). Seasonal effects can operate independently of priority effects, but both are important processes that need to be better understood.

While much work has focused on priority effects and seasonal effects in interspecific competition among amphibians, insects, mammals and marine fishes (Wilbur \& Alford, 1985; Louette \& De Meester, 2007; Körner et al., 2008; Ohashi et al., 2008; Geange \& Stier, 2009), less attention has been paid to freshwater fishes. An important example concerning freshwater fishes relates to interactions among gizzard shad Dorosoma cepedianum Lesueur, threadfin shad Dorosoma petenense Günther and bluegill sunfish Lepomis macrochirus Rafinesque in hyper-eutrophic reservoirs. Gizzard shad and threadfin shad often spawn earlier than bluegills and can reach high densities, reducing zooplankton abundance prior to the arrival of larval bluegills (Dettmers \& Stein, 1992; Devries \& Stein, 1992; Garvey \& Stein, 1998). When gizzard shad arrive earlier, a reduction in zooplankton often results in slow growth of bluegills and a potential reduction in subsequent recruitment (Devries \& Stein, 1992; Garvey \& Stein, 1998). However, the magnitude of these effects is less severe when seasonal reproduction by gizzard shad and bluegills is temporally aligned (Garvey \& Stein, 1998).

A similar situation may occur in other freshwater fishes that share a common resource and where the order and magnitude of emergence influences their interactions. Yellow perch, Perca flavescens Mitchill, and bluegills are sympatric in many northern North American freshwaters. Spawning phenologies differ, with yellow perch spawning prior to bluegills each year (Isermann \& Willis, 2008; Jolley, Edwards \& Willis, 2009). Larvae of both species become limnetic and forage primarily on zooplankton (Partridge \& Devries, 1999; Wu and Culver 1992). Age-0 yellow perch are often among the earliest species to hatch in northern latitude systems and may be able to capitalise on available resources before arrival of age-0 bluegill. Potential interspecific competition between these two species has not yet been examined.

Daphnia spp. (hereafter referred to as Daphnia) are an important prey item for bluegills and yellow perch during their first year of life (Hansen \& Wahl, 1981; Partridge \& Devries, 1999; Jolley, Willis \& Holland, 2010). This is probably attributable to the size of Daphnia and energetic return compared with other zooplankters (Werner \& Hall, 1974). Age-0 yellow perch select positively for Daphnia (Hansen \& Wahl, 1981; Mills \& Forney, 1983; Fulford et al., 2006), and Daphnia have also been shown to be the preferred prey of age-0 bluegill in many systems (Beard, 1982; Partridge \& Devries, 1999; Jolley et al., 2010).
Therefore, Daphnia availability may enhance growth, increase survival and increase recruitment to the adult life stage in both yellow perch and bluegills (Mills \& Forney, 1981; Mills, Sherman \& Robson, 1989).

In many freshwater ecosystems, Daphnia can reach moderate to high densities in the spring before populations eventually decline by summer [also referred to as a midsummer decline (MSD), MSD; Threlkeld, 1979]. Several mechanisms have been shown to influence Daphnia abundance in lakes, including grazing by zooplanktivorous fishes (Mills \& Forney, 1981; Cryer, Peirson \& Townsend, 1986; Whiteside, 1988; Vijverberg et al., 1990), reductions or changes in food quality for Daphnia (Threlkeld, 1985; Lampert et al., 1986; McCauley \& Murdoch, 1987), invertebrate predation (Wright, 1965; De Bernardi \& Giussani, 1975; Hoffman, Smith \& Lehman, 2001) and abiotic factors (Benndorf et al., 2001; Dupuis \& Hann, 2009). Mills \& Forney (1983) found that age-0 yellow perch could regulate the production of Daphnia pulex in Oneida Lake (New York State) if yellow perch densities exceeded 20-40 kg hectare ${ }^{-1}$. In contrast, Wu \& Culver (1994) attributed the initiation of the MSD to both age- 0 yellow perch predation and limited food availability in Lake Erie and hypothesised that prolonged reductions in Daphnia abundance were linked to total abundance of planktivorous fishes.

In this study, we use a 7-year data set to explore relationships among Daphnia biomass, yellow perch predation and age-0 bluegill growth in Pelican Lake, NE, U.S.A. We hypothesised that because yellow perch predation on Daphnia can be substantial (Mills \& Forney, 1981), it could ultimately reduce Daphnia biomass prior to the arrival of age-0 bluegill (i.e. priority effects). Because Daphnia are often positively selected by age- 0 bluegills (Partridge \& Devries, 1999; Jolley et al., 2010), a reduction in available Daphnia biomass may subsequently reduce growth rate and lower survival at the bluegill juvenile life stage.

\section{Methods}

\section{Study area}

Pelican Lake is a 332 ha, shallow (mean depth $=1.3 \mathrm{~m}$ ) natural lake in the Sandhills region of north-central Nebraska within the Valentine National Wildlife Refuge. Total vegetation cover during peak foliage (emergent and submergent combined) ranged from 40 to $52 \%$ during midsummer in 2004 and 2005 (Jolley, 2009). The fish assemblage is comprised primarily of bluegill, yellow perch, largemouth bass Micropterus salmoides Lacepéde, 
northern pike Esox lucius Linnaeus, black bullhead Ameiurus melas Rafinesque, common carp Cyprinus carpio Linnaeus and fathead minnow Pimephales promelas Rafinesque.

\section{Seasonal Daphnia biomass}

Zooplankton were collected every 10 day from late April to late August or early September from 2004 to 2010 using a 2-m-long tube sampler (diameter $=7.5 \mathrm{~cm}$; Rabeni, 1996). The lake was divided into 16 quadrats. Ten of those quadrats were randomly sampled during 20042008 , and five quadrats were randomly sampled during 2009-2010. Fewer samples were taken later in the study, as very few spatial differences existed in zooplankton densities during 2004-2008 (Kaemingk et al., 2011), suggesting that fewer samples could be collected without compromising the ability to accurately assess zooplankton community composition and density. Two zooplankton samples were collected at each quadrat and filtered through a $65-\mu \mathrm{m}$ mesh net, stored in $90 \%$ ethanol and then processed separately. Zooplankton were enumerated and identified to genus for cladocerans (e.g. Bosmina, Chydorus, Daphnia, Ceriodaphnia) and copepods (e.g. Cyclops, Diaptomus), or as copepod nauplii. Each sample was diluted with water to a measured volume of $30 \mathrm{~mL}$. Three subsamples were taken with a 5-mL HensenStempel pipette and placed in a Ward counting wheel. Zooplankters were enumerated in each subsample, and the total number of each taxon in a sample was calculated by dividing the number of organisms counted by the proportion of the sample volume processed. Density was calculated by multiplying the number of zooplankters of each taxon by the volume of the water filtered with the tube sampler. Up to 20 individuals per taxon were measured [nearest $0.01 \mathrm{~mm}$, total length (TL)] from each sample, and taxon-specific, length-dry weight conversions were used to convert length to biomass (mg). Biomass was then converted to wet weight using a dry mass-wet weight ratio of 0.10 for cladocerans and 0.12 for copepods (Cummins \& Wuycheck, 1971; Dumont, Velde \& Dumont, 1975; McCauley \& Kalff, 1981; Culver et al., 1985).

We defined the MSD in Daphnia abundance as the period after the spring peak when densities declined below $1.0 \mathrm{mg}$ wet weight $\mathrm{L}^{-1}$ (Benndorf et al., 2001). Three patterns of MSD were identified according to Benndorf et al. (2001) and characterised as pulsed, prolonged or absent. A pulsed MSD was characterised by a decline in Daphnia biomass $\left(<1.0 \mathrm{mg}\right.$ wet weight $\left.\mathrm{L}^{-1}\right)$ for $<30$ days. A prolonged MSD was defined as a decline in
Daphnia biomass lasting longer than 30 days. Finally, if Daphnia biomass did not fall below $1.0 \mathrm{mg}$ wet weight $\mathrm{L}^{-1}$, we considered MSD as absent.

\section{Relationship of MSD to phytoplankton and age-0 yellow perch abundance}

Phytoplankton abundance was measured as an index of food availability for Daphnia. We quantified phytoplankton biomass for each quadrat using chlorophyll- $a$ estimated from integrated water samples ( $N=2$ /quadrat) that were collected using a 2-m-long tube sampler. Ten quadrats were randomly sampled during 2004-2008 and five quadrats during 2009-2010 (same quadrats sampled for zooplankton). Samples were strained through glass microfibre filters $(0.7 \mu \mathrm{m})$ in the field and extracted in the laboratory following the methods described by Lind (1985).

Age-0 yellow perch and bluegill TL $\leq 25 \mathrm{~mm}$ were sampled concurrently with zooplankton and indexed using a surface trawl with a 0.76 -m-diameter opening and 1-mm mesh (bar measure) towed in large ellipses. Trawl duration was approximately $3-5 \mathrm{~min}$ at an estimated speed of $1.75 \mathrm{~m} \mathrm{~s}^{-1}$. The lake was divided into 16 quadrats; ten quadrats were randomly selected and trawled on each occasion (same quadrats sampled for zooplankton and phytoplankton plus five additional quadrats in 2009-2010). The amount of water volume sampled was calculated using a flow meter (Ocean Test Equipment, Inc., Fort Lauderdale, FL, U.S.A.) mounted in the mouth of the trawl. All age- 0 samples were preserved in $70 \%$ ethanol and transported to the laboratory for identification and analysis. All field data collection occurred during daylight hours. Age-0 fishes were identified to genus using identification keys (Auer, 1982; Holland-Bartels, Littlejohn \& Huston, 1990). All fishes were enumerated, and up to 200 randomly selected fish per sample for each species were measured for TL to the nearest $\mathrm{mm}$.

\section{Diet of age-0 fishes}

Digestive tracts were removed from up to 30 randomly selected yellow perch and bluegill per sampling occasion during 2004 and 2005 in Pelican Lake. Diet items were enumerated and identified to genus for all zooplankton taxa except for the family Daphniidae, which included both Daphnia and Ceriodaphnia, and were measured to the nearest $0.01 \mathrm{~mm}$; information on zooplankton lengths was used to estimate biomass as previously described. Relative prey importance for both age-0 bluegill and yellow 
perch was assessed using the Costello (1990) graphical method as modified by Amundsen, Gabler \& Staldvik (1996) where prey-specific abundance $\left(P_{i}\right)$ is calculated as

$$
P_{i}=\left(\frac{\Sigma S_{i}}{\Sigma S_{t i}}\right) \times 100
$$

where $P_{i}$ is the prey-specific abundance of prey $i, S_{i}$ the stomach content in dry weight comprised of prey $i$ and $S_{t i}$ the total stomach content in dry weight in only fishes containing prey $i$ in their stomach. Prey-specific abundance $\left(\mathrm{P}_{i}\right)$ is then plotted against the frequency of occurrence of each prey item to interpret feeding patterns. In a biplot of these variables, prey items located in the upper right-hand corners of the graph represent taxa with large frequency of occurrence and prey-specific abundance, and are characterised as important and dominant prey items. Prey items located in the lower left-hand corners of the graph reflect a low frequency of occurrence and prey-specific abundance and represent less important and rare items (Amundsen et al., 1996).

The proportion of diets (by wet weight) containing Daphniidae was plotted against age-0 yellow perch (2004) and bluegill (2005) TL to examine at which size each species could presumably begin feeding on Daphniidae. A logistic equation (PROC NLIN, SAS Institute Inc. 2003) was used to fit an S-shaped curve to examine the inflection point (i.e. the size at which they begin to feed on Daphniidae) and overall significance of the model. The TL inflection point was then used to determine the lower bounds for further size analyses. We used $25 \mathrm{~mm}$ as the cut-off (i.e. upper bound) because age-0 fish (i.e. yellow perch, bluegill) $>25 \mathrm{~mm}$ TL were infrequently represented in the samples, suggesting avoidance of the trawl or that a habitat shift had occurred.

\section{Age-0 yellow perch consumption}

To explore the extent of age- 0 yellow perch consumption of zooplankton resources (Daphniidae), we used bioenergetics modelling (Fish Bioenergetics 3.0; Hanson et al., 1997) to estimate Daphnia consumption by age-0 yellow perch. Information on water temperature, zooplankton energy density and fish growth collected in 2004 was used as inputs in the model to estimate yellow perch consumption. Temperature data were recorded hourly from a $\mathrm{HOBO}$ pendant data logger (Onset Computer Corporation, Bourne, Massachusetts 02532) placed near the bottom of Pelican Lake. Energy density values $\left(\mathrm{J} \mathrm{g}^{-1}\right.$ wet weight) for each zooplankton taxon were obtained from the literature (Cummins \& Wuycheck, 1971; Hanson et al., 1997). Mean TL of age-0 yellow perch for each sampling date was used to estimate wet weight (g) using the formula provided by Rose et al. (1999), which allowed initial and final weight to be assigned for the modelling simulation. The proportion of maximum consumption $(p)$ was fit according to the observed growth between sampling dates. Daily zooplankton consumption $\left(\mathrm{mg} \mathrm{day}^{-1}\right)$ by an age- 0 yellow perch was then multiplied by the density of age- 0 yellow perch $\left(\mathrm{mg} \mathrm{m}^{-3}\right.$ day $\left.^{-1}\right)$ and compared with mean Daphniidae standing stocks $\left(\mathrm{mg} \mathrm{m}^{-3}\right)$ in Pelican Lake.

\section{Age-0 bluegill Daphnia availability and growth}

We attempted to collect and age a minimum of 30 age- 0 bluegill (TL 10.1-25 mm) from the first 10-day cohort to hatch each year. Because of high larval mortality (i.e. few surviving past 25 day), we aged 5-12 age-0 bluegill from the first cohort each year from 2004 to 2010. TL (mm) was also measured to determine cohort growth rates $\left(\mathrm{mm} \mathrm{day}{ }^{-1}\right)$ each year. We hypothesised that age-0 bluegill growth rates would increase as a result of higher available biomass of Daphnia. Sagittal otoliths of age-0 bluegill were aged by two independent readers using a compound microscope, and daily age estimates were averaged if they were within $10 \%$ of each other (Santucci \& Wahl, 2003). A third experienced reader was consulted if there was disagreement between readers, and the otolith was read in concert until consensus was reached. If all readers failed to reach an agreement, then the otolith was removed from the data set $(2 \%$ were removed). Taubert \& Coble (1977) reported that the first growth increment occurred at swim-up for bluegill; Garvey, Herra \& Leggett (2002) confirmed this and reported that swim-up occurred approximately 3 day post-hatching. Therefore, hatching date for individual bluegill was calculated by adding 3 day to the growth increment count. We examined growth effects on the first 10-day cohort of age-0 bluegill in relation to Daphnia biomass because density-dependent effects could be minimised, and any negative effects caused by interspecific competition (i.e. yellow perch) would probably be portrayed in this cohort because of the timing of their arrival (i.e. closest cohort to age-0 yellow perch arrival).

Differences in daily growth rates of age-0 bluegills were assessed between years using analysis of variance (ANOVA). A mixed model (PROC MIXED, SAS Institute Inc. 2003) using the maximum likelihood method allowed detection of differences in growth rates between years with an unbalanced design (e.g. more individuals for 

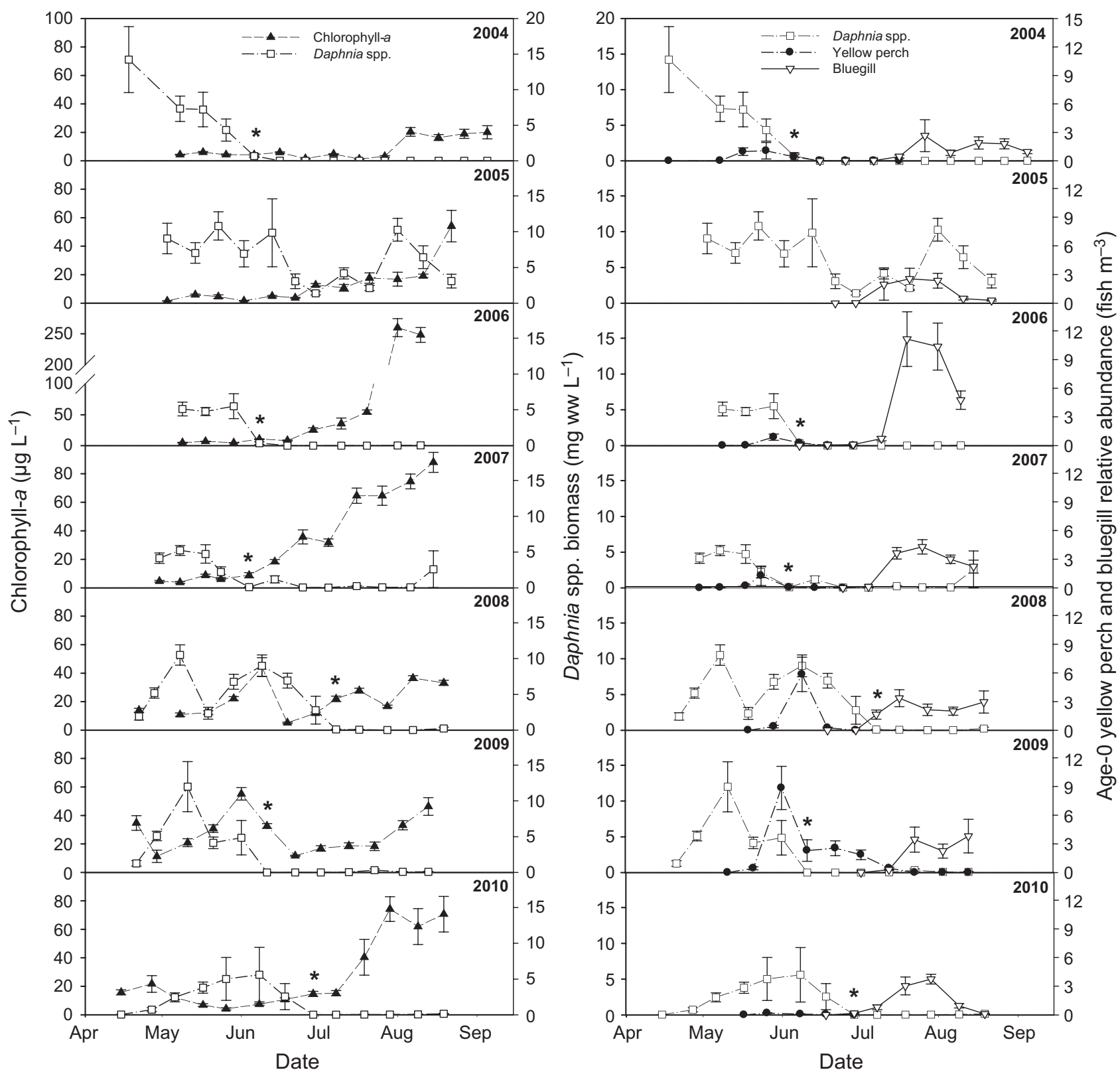

Fig. 1 Time series data for Daphnia spp. biomass (mg ww L $\left.{ }^{-1}\right)$ and chlorophyll-a $\left(\mu \mathrm{g} \mathrm{L}^{-1}\right.$; left panel) and phenology of Daphnia spp. biomass ( $\mathrm{mg} \mathrm{ww} \mathrm{L}^{-1}$ ), age-0 yellow perch $[12.8 \mathrm{~mm}<$ total length $(\mathrm{TL})<25 \mathrm{~mm}]$ and age-0 bluegill $\left(10.1 \mathrm{~mm}<\mathrm{TL}<25 \mathrm{~mm}\right.$ ) relative abundance (fish $\mathrm{m}^{-3}$ ) in Pelican Lake, NE, from 2004 to 2010 (right panel). Asterisks denote timing of the Daphnia spp. midsummer decline.

some years; Littell et al., 1996). Tukey's post hoc comparisons were used to identify where differences occurred among years.

\section{Results}

Seasonal Daphnia biomass

Peak spring Daphnia biomass ranged from 5.2 (2007) to 14.1 (2004) mg wet weight $\mathrm{L}^{-1}$. Daphnia in Pelican Lake experienced a prolonged MSD during all years examined except during 2005 when no MSD was observed (Fig. 1). The MSD typically occurred within the first 2 weeks of June, but MSD was delayed and occurred at the end of June in 2008 and 2010 (Fig. 1). Mean overall Daphnia biomass each year ranged from 1.57 (2006 and 2010) to 6.18 (2005) $\mathrm{mg}$ wet weight $\mathrm{L}^{-1}$ (Table 1). Daphnia was the dominant zooplankter during 2005, whereas in all other years, Daphnia were replaced by other cladocerans later in the season (Fig. 2).

(c) 2012 Blackwell Publishing Ltd, Freshwater Biology, 57, 654-665 
Table 1 Overall mean (across all sampling dates), standard error (SE), minimum (Min) and Maximum (Max) Daphnia spp. biomass (mg wet weight $\left.\mathrm{L}^{-1}\right)$ and chlorophyll- $a\left(\mu \mathrm{g} \mathrm{L}^{-1}\right)$ in Pelican Lake from 2004 to 2010

\begin{tabular}{|c|c|c|c|c|c|c|c|c|}
\hline \multirow[b]{2}{*}{ Year } & \multicolumn{4}{|c|}{ Daphnia spp. biomass (mg ww $\mathrm{L}^{-1}$ ) } & \multicolumn{4}{|c|}{ Chlorophyll- $a\left(\mu \mathrm{g} \mathrm{L}^{-1}\right)$} \\
\hline & Mean & SE & Min & $\operatorname{Max}$ & Mean & SE & Min & $\operatorname{Max}$ \\
\hline 2004 & 2.41 & 1.16 & 0.00 & 14.22 & 8.56 & 2.05 & 1.27 & 20.34 \\
\hline 2005 & 6.18 & 0.97 & 1.39 & 10.80 & 12.81 & 4.17 & 1.58 & 54.09 \\
\hline 2006 & 1.57 & 0.78 & 0.00 & 5.50 & 65.80 & 31.80 & 4.61 & 259.70 \\
\hline 2007 & 1.72 & 0.58 & 0.03 & 5.23 & 34.14 & 8.93 & 3.80 & 88.06 \\
\hline 2008 & 3.53 & 1.04 & 0.01 & 10.51 & 21.41 & 3.43 & 5.19 & 44.32 \\
\hline 2009 & 2.32 & 1.06 & 0.00 & 11.99 & 27.53 & 3.96 & 11.30 & 55.13 \\
\hline 2010 & 1.57 & 0.58 & 0.02 & 5.61 & 27.33 & 7.06 & 4.16 & 74.19 \\
\hline
\end{tabular}

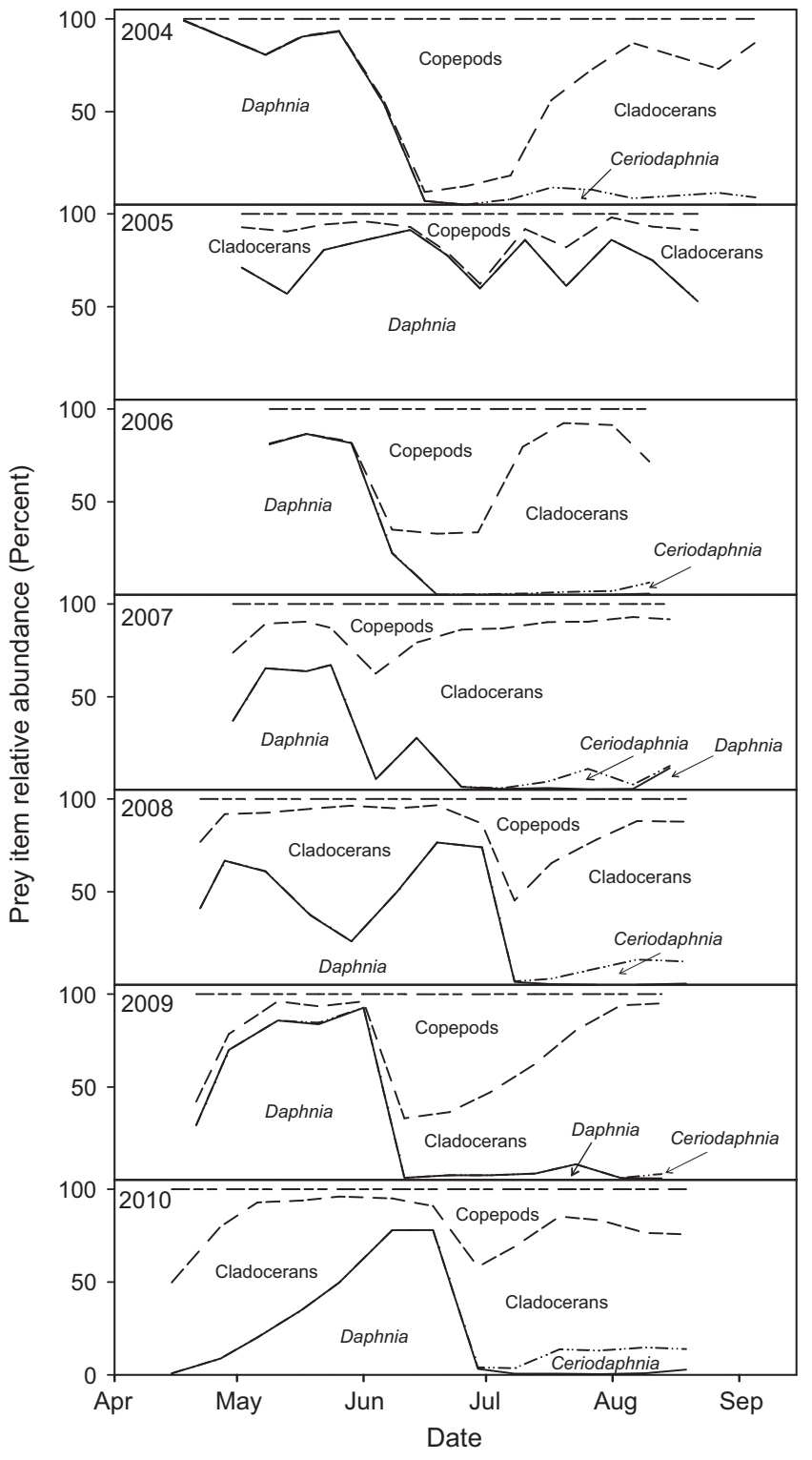

Fig. 2 Relative abundance by per cent biomass (dry weight) of four prey types in field samples collected during 2004-2009 in Pelican Lake, Nebraska. From the bottom of each panel to the top, prey items are Daphnia spp., Ceriodaphnia, remaining other cladocerans and copepods.
Relationship of MSD to phytoplankton and age-0 yellow perch abundance

At the time of the Daphnia MSD, chlorophyll- $a$ values ranged from 4.3 (2007) to 32.6 (2009) $\mu \mathrm{g} \mathrm{L}^{-1}$ (Fig. 1). Mean chlorophyll- $a$ concentration was lower in 2005 compared with all years except 2004, when standing stock of both algae and zooplankton was generally low (Table 1). Typically, chlorophyll- $a$ densities remained low early in the season and peaked in August. However, in 2008 and 2009, chlorophyll- $a$ densities peaked in June, prior to the Daphnia MSD (Fig. 1).

The timing of peak age- 0 yellow perch abundance $(12.8 \mathrm{~mm}<\mathrm{TL}<25 \mathrm{~mm})$ was during the last week in May or the first week of June, with the earliest date in 2007 (24May) and the latest in 2008 (9-June; Fig. 1). No age-0 yellow perch $(12.8 \mathrm{~mm}<\mathrm{TL}<25 \mathrm{~mm})$ were collected in 2005, suggesting a potential year class failure (Jolley \& Willis, 2009). The MSD followed (10 day post) peak age-0 yellow perch abundance each year except in 2008 and 2010 when Daphnia densities did not fall below $1 \mathrm{mg}$ wet weight $\mathrm{L}^{-1}$ until 29 and 34 days, respectively (Fig. 1). Daphnia biomass ranged from 2.2 (2007) to 9.0 (2008) mg wet weight $\mathrm{L}^{-1} \quad\left(\right.$ mean $=5.2 \mathrm{mg}$ wet weight $\mathrm{L}^{-1}$ ) during peak age-0 yellow perch abundance. However, mean Daphnia biomass was generally below $5.5 \mathrm{mg}$ wet weight $\mathrm{L}^{-1}$ during all years except 2008, when mean biomass was nearly twice as high (Fig. 2). Peak age-0 yellow perch densities ranged from 0.2 (2010) to 8.9 (2009) yellow perch $\mathrm{m}^{-3}$ (mean $=3.0$ yellow perch $\mathrm{m}^{-3}$; Fig. 1 ).

\section{Diet of age-0 fishes}

Prior to age-0 yellow perch reaching $12.8 \mathrm{~mm} \mathrm{TL}$, the most important zooplankter in the diet was Cyclops in 2004 (Fig. 3a,b). When age-0 yellow perch larvae reached a size at which they could potentially consume Daphniidae (i.e. $>12.8 \mathrm{~mm}$ ), these became the most important and 


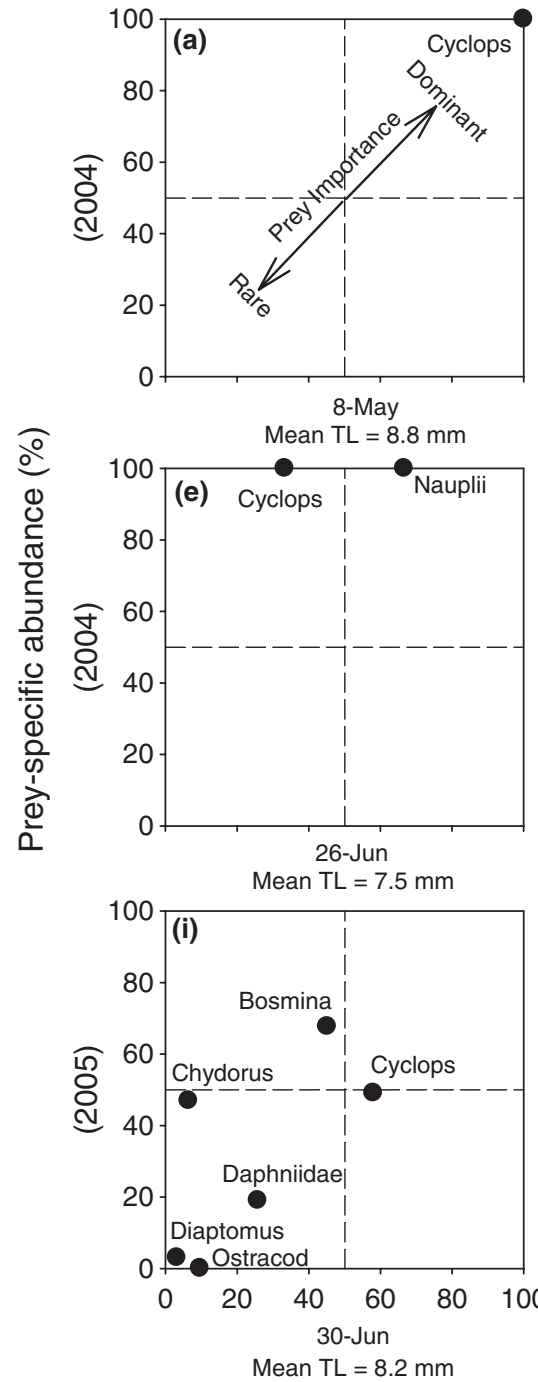

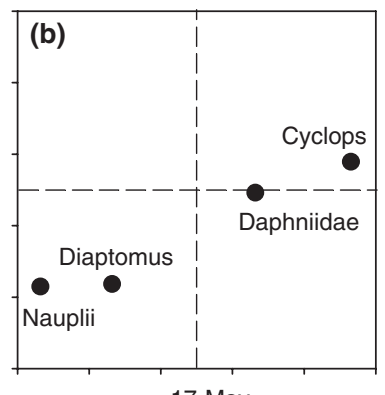

17-May

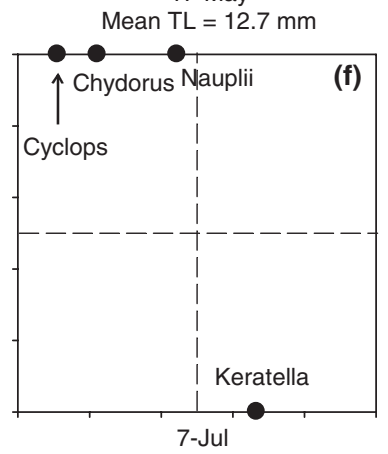

Mean TL $=9.1 \mathrm{~mm}$

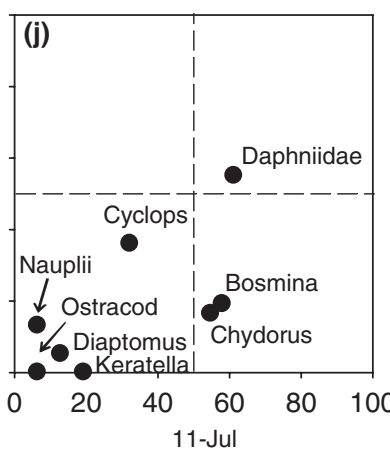

Mean TL $=10.6 \mathrm{~mm}$

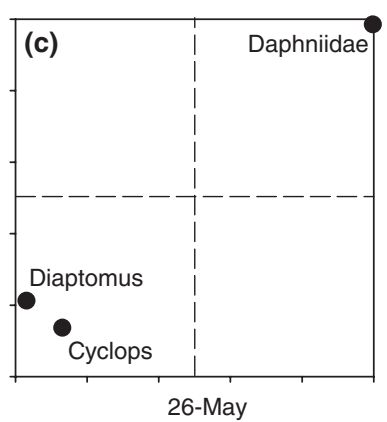

Mean $\mathrm{TL}=17.1 \mathrm{~mm}$

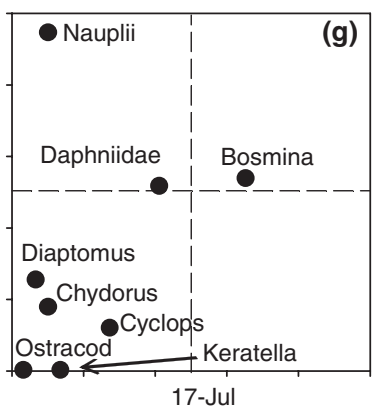

Mean $\mathrm{TL}=10.8 \mathrm{~mm}$

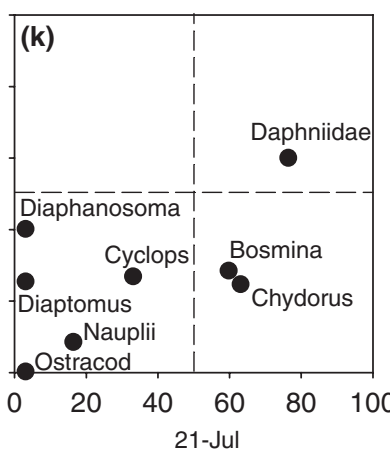

Mean TL $=10.4 \mathrm{~mm}$

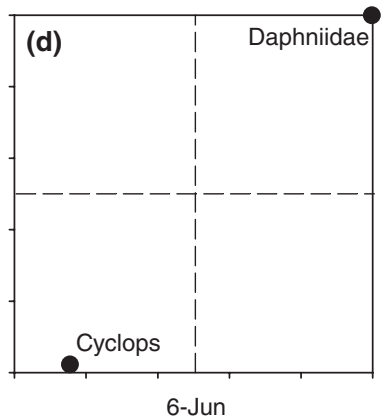

Mean $\mathrm{TL}=22.4 \mathrm{~mm}$

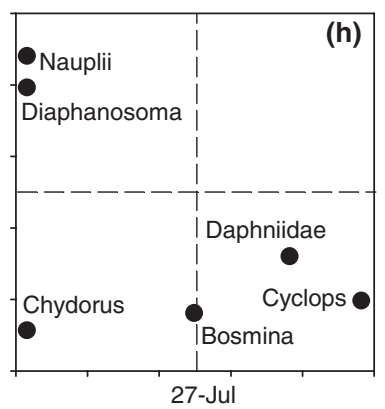

Mean TL $=15.0 \mathrm{~mm}$

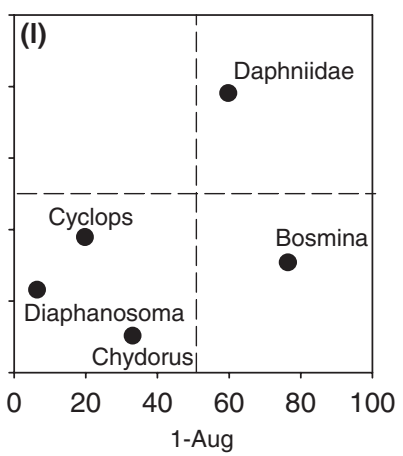

Mean TL $=11.4 \mathrm{~mm}$

Frequency of occurence

Fig. 3 Graphical analysis of age-0 yellow perch (a-d) and age-0 bluegill (e-1) diets in Pelican Lake, NE, during 2004 (bluegill and yellow perch) and 2005 (bluegill). Sampling dates and age-0 fish mean total length are shown on the $x$-axis. All age-0 yellow perch stomachs in 2005 were empty. See text for more details on the methods used for calculating the graphical technique presented in this figure.

dominant prey item by both per cent weight and frequency of occurrence in late May and early June (Fig. 3c,d). The few age-0 yellow perch larvae (i.e. $<12.8 \mathrm{~mm}$ ) we collected in 2005 had empty stomachs.

During 2004, age-0 bluegill (mean TL $=7.5 \mathrm{~mm}$ ) predominantly consumed copepod nauplii through mid-July (Fig. 3e,f), but later switched to Bosmina (mean $\mathrm{TL}=10.8 \mathrm{~mm}$; Fig. 3g). Daphniidae was not a dominant prey item during any sampling period in 2004 (Fig. 3). In contrast, Cyclops was an important diet item for first-feeding age-0 bluegill in 2005 (Fig. 3i; mean $\mathrm{TL}=8.3 \mathrm{~mm}$ ), but bluegill switched to predominantly Daphniidae by midJuly (Fig. 3j-1).

We found a significant relationship between the proportion by wet weight of Daphniidae in the diets and TL for yellow perch $\left(F_{3,115}=158.06, P<0.0001\right)$ and bluegill $\left(F_{3,118}=55.49, P<0.0001\right.$; Fig. 4$)$. Size-dependent consumption, determined from the logistic model, revealed that yellow perch were able to consume Daphniidae at $12.8 \mathrm{~mm}$ and bluegill at $10.1 \mathrm{~mm}$ (i.e. inflection point values; Fig. 4). Prior to age-0 yellow perch reaching $12.8 \mathrm{~mm}, 81.8 \%(36 / 44)$ of the individuals examined in 2004 did not consume any Daphniidae (Fig. 4). The percentage of age- 0 bluegill $<10.1 \mathrm{~mm}$ that did not consume Daphniidae in 2005 was 69.7\% (46/66; Fig. 4).

\section{Age-0 yellow perch consumption}

Bioenergetics modelling revealed that age-0 yellow perch could potentially consume 1.3 (17 May 2004) to 

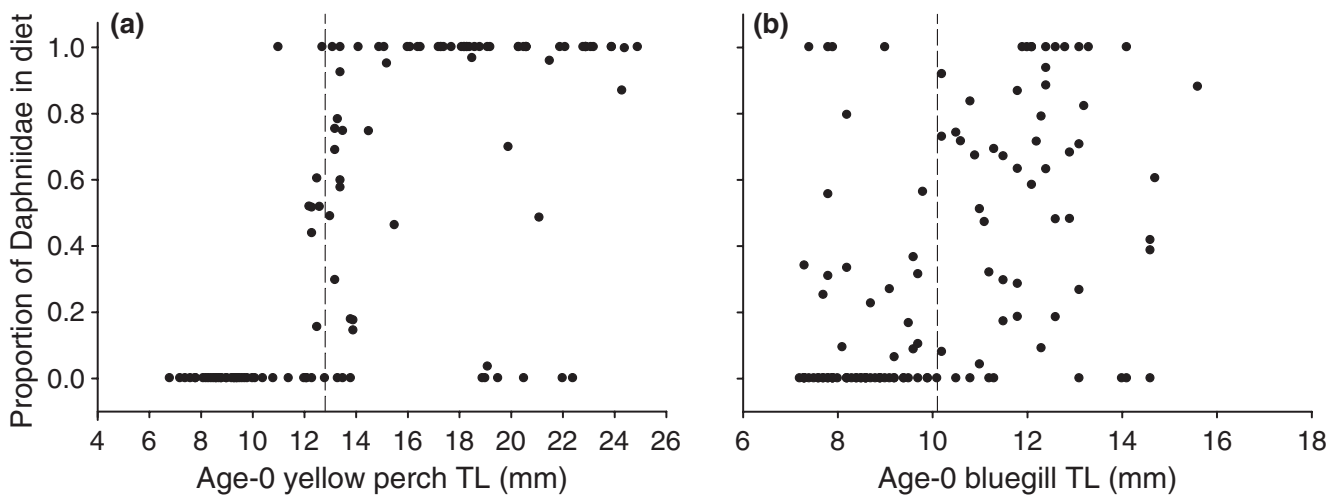

Fig. 4 Proportion of Daphnia spp. by dry weight in diets of individual age-0 yellow perch in 2004 (a) and bluegill in 2005 (b) across multiple total lengths $(\mathrm{mm})$. Vertical dashed line is the inflection point indicating the size at which the population of age-0 fishes began consuming Daphnia spp.

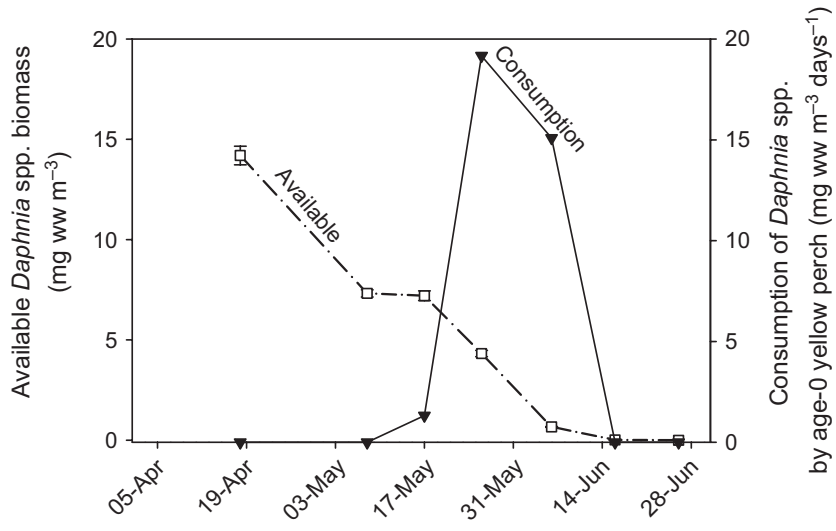

Fig. 5 Consumption of Daphnia spp. $\left(\mathrm{mg} \mathrm{ww}^{-3}\right.$ day $\left.^{-1}\right)$ by age- 0 yellow perch compared with the standing stock of available Daphnia spp. $\left(\mathrm{mg} \mathrm{ww} \mathrm{m}^{-3}\right.$ ) in Pelican Lake, NE, in 2004 as estimated from bioenergetics modelling.

19.2 (26 May 2004) $\mathrm{mg}$ wet weight $\mathrm{m}^{-3}$ day $^{-1}$ of Daphnia. As a result, yellow perch consumption was lower than the available standing stock biomass of Daphnia on 17 May 2004. However, consumption exceeded the Daphnia standing stock on 26 May and 6 June 2004 (Fig. 5).

\section{Daphnia availability and age-0 bluegill growth}

In allyears except2005, Daphnia biomass generally remained below $0.3 \mathrm{mg}$ wet weight $\mathrm{L}^{-1}$ following the appearance of the first 10-day cohort of age-0 bluegill able to consume Daphnia (i.e. >10.1 mm). In some years (i.e. 2004 and 2006), Daphnia were not present in any samples when the first 10-day cohort of age-0 bluegill $(>10.1 \mathrm{~mm})$ was detected (Fig. 6). In 2005, however, Daphnia biomass was appreciably greater than other years, with a mean value of $4.2 \mathrm{mg}$ wet weight $\mathrm{L}^{-1}$ (Fig. 6).

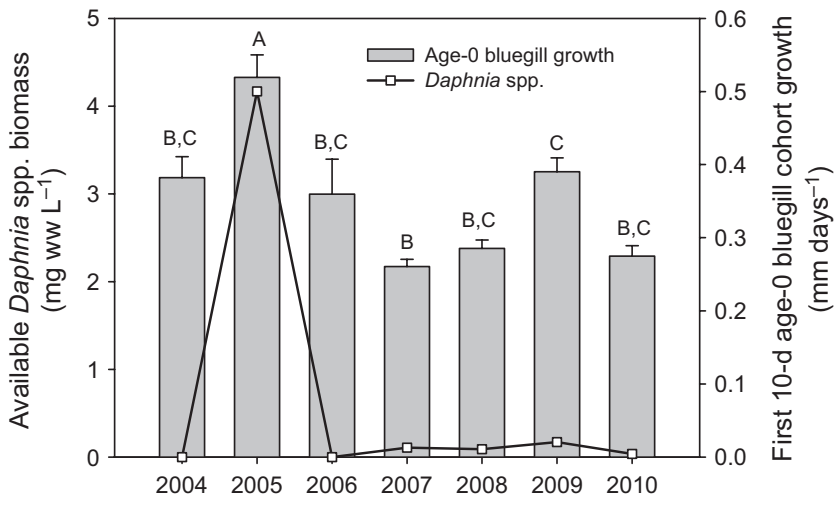

Fig. 6 Daphnia spp. biomass $\left(\mathrm{mg} \mathrm{ww}^{-1}\right)$ and mean $( \pm$ SE) first 10-day age-0 bluegill cohort daily growth $\left(\mathrm{mm} \mathrm{day}^{-1}\right)$ during the period when the first 10-day age-0 bluegill cohort could potentially consume Daphnia spp. in Pelican Lake, NE, in 2004-2010. Letters indicate significant differences in age- 0 bluegill growth between years.

Daily growth of age-0 bluegill ranged from 0.26 (2007) to 0.52 (2005) $\mathrm{mm} \mathrm{day}^{-1}$ (mean $=0.35 \mathrm{~mm} \mathrm{day}^{-1}$; Fig. 6). Daily growth rates differed between bluegill cohorts across years $\left(F_{6,51}=13.19, P<0.0001\right)$ with growth in 2005 significantly greater than in all other years $(P<0.01$; Fig. 6). Daily growth rates were also significantly greater during 2009 than $2007 \quad\left(t_{1,51}=-3.09\right.$, $P=0.048$; Fig. 6). No other significant differences were found for age-0 bluegill growth rates between years $(P>0.05$; Fig. 6).

\section{Discussion}

This study documents priority effects between age- 0 yellow perch and bluegill relating to an important prey resource. Age- 0 yellow perch have an advantage over the first age- 0 bluegill cohort in Pelican Lake by arriving 
earlier and capitalising on abundant Daphnia, which become limiting, prior to the arrival of age-0 bluegill. Age-0 bluegill growth was significantly slower in years when age-0 yellow perch were present compared with 2005 when no age-0 yellow perch were sampled. Daphnia persisted throughout 2005, and, as a result, bluegills were able to use this resource and ultimately experience faster growth rates; increased growth could lead to higher survival and subsequent recruitment.

The MSD in Daphnia biomass occurred within 10 day of peak age- 0 yellow perch abundance in all years except in 2008 and 2010. However, in some years (i.e. 2004, 2009), Daphnia biomass was already declining prior to the arrival of age- 0 yellow perch, implying that age- 0 yellow perch are not solely responsible for the MSD, but when Daphnia biomass is low and age- 0 yellow perch are present, they have the potential to suppress Daphnia biomass to low levels (i.e. $<1.0 \mathrm{mg}$ wet weight $\mathrm{L}^{-1}$ ). Similar observations have been reported in other studies where planktivorous fish abundance has been attributed to the Daphnia collapse when densities were already low, particularly later in the season following a decline in Daphnia fecundity (Wu \& Culver, 1994; Boersma, Van Tongeren \& Mooij, 1996; Mehner et al., 1998). In contrast, some studies indicate that planktivorous fishes play a key role in the suppression of Daphnia (Mills \& Forney, 1983; Cryer et al., 1986; Whiteside, 1988). Other species in Pelican Lake, such as black bullhead, age-0 largemouth bass and fathead minnow, may also influence the abundance of Daphnia. However, it seems probable that yellow perch contributed to the Daphnia decline for at least two reasons: (i) other fishes typically hatch after yellow perch in Pelican Lake and (ii) the decline in Daphnia biomass was concomitant with peak age-0 yellow perch abundance in most years.

In 2004, Daphniidae was an important prey item for yellow perch, as reported in other studies (Mills \& Forney, 1983; Fulford et al., 2006). The timing of Daphnia MSD aligned with the arrival of age- 0 yellow perch with the exception of 2008 and 2010. These 2 years were different than other years with respect to overall Daphnia biomass and age- 0 yellow perch abundance. During peak age- 0 yellow perch abundance in 2008, Daphnia biomass exceeded densities observed during other years. In contrast, peak age- 0 yellow perch abundance was lowest in 2010 compared with all other years examined. As a result, age- 0 yellow perch predation may not have been able to effectively reduce Daphnia biomass via predation.

Bioenergetics modelling revealed that age- 0 yellow perch have the potential to consume a substantial amount of Daphnia biomass. We found that in two of seven dates in 2004, daily consumption by age-0 yellow perch exceeded Daphnia biomass in Pelican Lake, supporting field patterns of age- 0 yellow perch and Daphnia biomass. Because the Daphnia life cycle is completed within 5.5-24 day (Allan, 1976), depending on water temperature, it is possible for consumption to exceed the standing stock, if predation is excessive. Collectively, these results indicate that age- 0 yellow perch have the potential to reduce Daphnia biomass via predation, particularly when densities are low (Mills \& Forney, 1983).

The MSD may be attributed to a limitation in food availability, as chlorophyll- $a$ concentrations in our study were substantially lower than a Lake Erie study (by a magnitude of 100), which recorded low Daphnia birth rates at densities much higher than recorded for Pelican Lake (Wu \& Culver, 1994). Furthermore, our chlorophyll- $a$ estimates probably overestimated the amount of available phytoplankton, because edible and non-edible phytoplankton were not separated. In addition to age-0 yellow perch predation, phytoplankton overgrazing could also lead to an MSD in Pelican Lake as found in two other studies (Threlkeld, 1979; Lampert et al., 1986). Factors such as invertebrate predation or temperature could have also played a role in the MSD observed in Pelican Lake (Wright, 1965; De Bernardi \& Giussani, 1975; Benndorf et al., 2001; Hoffman et al., 2001; Dupuis \& Hann, 2009), but isolating these factors was beyond the scope of this study.

Age-0 bluegill growth was significantly faster during 2005 (in the absence of age- 0 yellow perch) potentially in response to increased availability of Daphnia compared with all other years. Diets of age-0 bluegill revealed that Daphniidae were not important in 2004. However, Daphniidae became very important in 2005 and consequently resulted in faster growth rates. Age-0 bluegill positively select Daphnia during their first year of life (Beard, 1982; Partridge \& Devries, 1999). Growth rates similar to the first 10-day age-0 bluegill cohort in 2005 were not observed in any other year as Daphnia densities remained scarce (below $0.3 \mathrm{mg}$ wet weight $\mathrm{L}^{-1}$ ) or were in such low densities that we did not detect them in our samples (0.0 mg wet weight $\mathrm{L}^{-1}$ ). In 2004, when Daphnia were not available, age- 0 bluegill diets followed a more generalised feeding pattern as opposed to a diet consisting primarily of Daphniidae in 2005 when Daphnia were available. Because Daphnia densities were reduced to such low levels (and thus are a limiting resource in Pelican Lake), age-0 yellow perch can outcompete age-0 bluegill for Daphnia because of differences in spawning phenologies.

Zooplankton assemblage and densities differed between 2004 and 2005, with no Daphnia sampled in Pelican Lake during 2004 when the first 10-day age-0 
bluegill cohort was present, but in 2005, Daphnia persisted throughout the summer. Likewise, Ceriodaphnia were at low abundance $\left(<0.12 \mathrm{~L}^{-1}\right)$ compared with Daphnia $\left(>20.4 \mathrm{~L}^{-1}\right)$ in 2005 during the time when age-0 bluegill could possibly consume them. Daphniidae was a more important prey item to age-0 bluegill in 2005 than in 2004. Therefore, age- 0 bluegill diets probably consisted primarily of Ceriodaphnia in 2004 and Daphnia in 2005, based on prey availability and importance in the diet. Furthermore, as found in other studies, Daphnia is often more important to age-0 bluegill than Ceriodaphnia (Beard, 1982; Partridge \& Devries, 1999). In addition, Ceriodaphnia were absent from most samples (a single date: $0.06 \mathrm{~L}^{-1}$ ) during the emergence of age- 0 yellow perch in 2004, indicating Daphnia is a more probable prey item consumed during this time. This also aligns with previous research that shows age-0 yellow perch often positively select Daphnia more often than Ceriodaphnia (Mills \& Forney, 1983; Fulford et al., 2006).

Several factors may act in combination to ultimately influence growth rates of the first 10-day age-0 bluegill cohort, including the timing of age- 0 yellow perch spawning, densities of age- 0 yellow perch, Daphnia densities and the timing of age-0 bluegill spawning. Age-0 yellow perch hatch before age- 0 bluegill, potentially giving them an advantage by preying upon Daphnia prior to the arrival of age- 0 bluegill. However, the priority effect advantage may be minimised depending on the time gap between hatching in these two species. Age-0 bluegill growth will typically respond positively when age-0 yellow perch delay spawning as opposed to when they initiate spawning earlier in the season. This may allow the temporal gap to be minimised, which could allow a carryover of Daphnia for age-0 bluegill to consume if age-0 yellow perch densities are low. A similar situation exists between gizzard shad and bluegill, where temporal alignment results in less negative effects for bluegill (Garvey \& Stein, 1998). When age-0 yellow perch spawning occurs later in the season, densities of age- 0 yellow perch are low, Daphnia densities are high and bluegill spawn earlier in the season, there could be enhanced bluegill growth because age- 0 yellow predation does not collapse Daphnia prior to the arrival of age-0 bluegill. We did not observe many of these scenarios in our study, but rather our intention was to provide a conceptual framework for future studies to test these hypotheses. Although situations may exist where age- 0 bluegill growth could respond positively, it appears that several factors have to align in concert for this to occur, and the likelihood of this is low. As a result, growth of the first 10-day age-0 bluegill cohort will be negatively affected most years in the presence of age- 0 yellow perch, as was found in our study.

\section{Acknowledgments}

We are grateful to all the technicians who assisted in the field and laboratory. M. Lindvall and Valentine National Wildlife Refuge provided access to Pelican Lake. We thank D. Graham, D. Hartmann, D. Krueger and the Valentine State Fish Hatchery for assistance. Thanks to M. Wuellner, SDSU Comprehensive Ecology and Fisheries Discussion Group, and two anonymous reviewers for reviewing earlier drafts of this manuscript. Funding for this project was provided by the Nebraska Game and Parks Commission through the Federal Aid in Sport Fish Restoration Project F-118-R. Any use of trade names is for descriptive purposes only and does not imply endorsement by the U.S. Government.

\section{References}

Allan J.D. (1976) Life history patterns in zooplankton. The American Naturalist, 110, 165-180.

Amundsen P.A., Gabler H.M. \& Staldvik F.J. (1996) A new approach to graphical analysis of feeding strategy from stomach contents data - modification of the Costello (1990) method. Journal of Fish Biology, 48, 607-614.

Auer N.A. (Ed.) (1982) Identification of Larval Fishes of the Great Lakes Basin with Emphasis on the Lake Michigan Drainage. Great Lakes Fishery Commission, Ann Arbor, MI, Special Publication 82-3.

Beard T.D. (1982) Population Dynamics of Young-of-the-Year Bluegill. Wisconsin Department of Natural Resources, Madison, WI, Technical Bulletin Number 127.

Benndorf J., Kranich J., Mehner T. \& Wagner A. (2001) Temperature impact on the midsummer decline of Daphnia galeata: an analysis of long-term data from the biomanipulated Bautzen Reservoir (Germany). Freshwater Biology, 46, 199-211.

Boersma M., Van Tongeren O.F. \& Mooij W.M. (1996) Seasonal patterns in the mortality of Daphnia species in a shallow lake. Canadian Journal of Fisheries and Aquatic Sciences, 53, 18-28.

Costello M.J. (1990) Predator feeding strategy and prey importance: a new graphical analysis. Journal of Fish Biology, 36, 261-263.

Cryer M., Peirson G. \& Townsend C.R. (1986) Reciprocal interactions between roach, Rutilus rutilus, and zooplankton in a small lake: prey dynamics and fish growth and recruitment. Limnology and Oceanography, 31, 10221038.

Culver D.A., Boucherle M.M., Bean D.J. \& Fletcher J.W. (1985) Biomass of freshwater crustacean zooplankton from 
length-weight regressions. Canadian Journal of Fisheries and Aquatic Sciences, 42, 1380-1390.

Cummins K.W. \& Wuycheck J.C. (1971) Caloric equivalents for investigations in ecological energetics. Mitteilungen der Internationale Vereinigung für Theoretische und Angewandte Limnologie, 18, 1-151.

De Bernardi R. \& Giussani G. (1975) Population dynamics of three cladocerans of Lago Maggiore related to predation pressure by a planktophagus fish. Verhandlungen der Internationale Vereinigung für Theoretische und Angewandte Limnologie, 19, 2906-2912.

Dettmers J.M. \& Stein R.A. (1992) Food consumption by larval gizzard shad: zooplankton effects and implications for reservoir communities. Transactions of the American Fisheries Society, 121, 494-507.

Devries D.R. \& Stein R.A. (1992) Complex interactions between fish and zooplankton: quantifying the role of an open-water planktivore. Canadian Journal of Fisheries and Aquatic Sciences, 49, 1216-1227.

Dumont H.J., Velde I. \& Dumont S. (1975) The dry weight estimate of biomass in a selection of Cladocera, Copepoda and Rotifera from the plankton, periphyton and benthos of continental waters. Oecologia, 19, 75-97.

Dupuis A.P. \& Hann B.J. (2009) Warm spring and summer water temperatures in small eutrophic lakes of the Canadian prairies: potential implications for phytoplankton and zooplankton. Journal of Plankton Research, 31, 489-502.

Fincke O.M. (1999) Organization of predator assemblages in Neotropical tree holes: effects of abiotic factors and priority. Ecological Entomology, 24, 13-23.

Fulford R.S., Rice J.A., Miller T.J., Binkowski F.P., Dettmers J.M. \& Belonger B. (2006) Foraging selectivity by larval yellow perch (Perca flavescens): implications for understanding recruitment in small and large lakes. Canadian Journal of Fisheries and Aquatic Sciences, 63, 28-42.

Garvey J.E. \& Stein R.A. (1998) Competition between larval fishes in reservoirs: the role of relative timing of appearance. Transactions of the American Fisheries Society, 127, 1021-1039.

Garvey J.E., Herra T.P. \& Leggett W.C. (2002) Protracted reproduction in sunfish: the temporal dimension in fish recruitment revisited. Ecological Applications, 12, 194-205.

Geange S.W. \& Stier A.C. (2009) Order of arrival affects competition in two reef fishes. Ecology, 90, 2868-2878.

Hall S.R. (2004) Stoichiometrically explicit competition between grazers: species replacement, coexistence, and priority effects along resource supply gradients. The American Naturalist, 164, 157-172.

Hansen M.J. \& Wahl D.H. (1981) Selection of small Daphnia pulex by yellow perch Fry in Oneida Lake, New York. Transactions of the American Fisheries Society, 110, 64-71.

Hanson P.C., Johnson T.B., Schindler D.E. \& Kitchell J.F. (1997) Fish Bioenergetics 3.0 for Windows. University of Wisconsin Sea Grant Institute, Report WISCU-T-97-001, Madison, WI.
Hoffman J.C., Smith M.E. \& Lehman J.T. (2001) Perch or plankton: top-down control of Daphnia by yellow perch (Perca flavescens) or Bythotrephes cederstroemi in an inland lake? Freshwater Biology, 46, 759-775.

Holland-Bartels L.E., Littlejohn S.K. \& Huston M.L. (1990) A Guide to Larval Fishes of the Upper Mississippi River. U.S. Fish and Wildlife Service, La Crosse, WI.

Isermann D.A. \& Willis D.W. (2008) Emergence of larval yellow perch, Perca flavescens, in South Dakota lakes: potential implications for recruitment. Fisheries Management and Ecology, 15, 259-271.

Jolley J.C. (2009) Recruitment of bluegill and yellow perch in Nebraska Sandhills lakes: integrating multiple lifestages. Doctoral dissertation, South Dakota State University, Brookings.

Jolley J.C. \& Willis D.W. (2009) Biotic communities in Nebraska sandhill lakes. Nebraska Game and Parks Commission, Federal Aid in Sport Fish Restoration, Project F-118-R, Study I, Segments 6-10, Final Report, Lincoln.

Jolley J.C., Edwards K.R. \& Willis D.W. (2009) Bluegill (Lepomis macrochirus) spawning periodicity and hatching duration in the Northern Great Plains, USA. Journal of Freshwater Ecology, 24, 29-38.

Jolley J.C., Willis D.W. \& Holland R.S. (2010) Matchmismatch regulation for bluegill and yellow perch larvae and their prey in Sandhill lakes. Journal of Fish and Wildlife Management, 1, 73-85.

Kaemingk M.A., Jolley J.C., Willis D.W. \& Graeb B.D.S. (2011) Exploring spatial distributions of larval yellow perch Perca flavescens, bluegill Lepomis macrochirus and their prey in relation to wind. Journal of Fish Biology, 78, 1132-1151.

Körner C., Stöcklin J., Reuther-Thiébaud L. \& Pelaez-Riedl S. (2008) Small differences in arrival time influence composition and productivity of plant communities. New Phytologist, 177, 698-705.

Lampert W., Fleckner W., Rai H. \& Taylor B.E. (1986) Phytoplankton control by grazing zooplankton: a study on the spring clear-water phase. Limnology and Oceanography, 31, 478-490.

Lawler S.P. \& Morin P.J. (1993) Temporal overlap, competition, and priority effects in larval Anurans. Ecology, 74, 174-182.

Lind O.T. (1985) Handbook of Common Methods in Limnology, 2nd edn. Kendall/Hunt Publishing Company, Dubuque, IA.

Littell R., Milliken F., Stroup W. \& Wolfinger R. (1996) SAS System for Mixed Models. SAS Institute, Cary, NC.

Louette G. \& De Meester L. (2007) Predation and priority effects in experimental zooplankton communities. Oikos, 116, 419-426.

McCauley E. \& Kalff J. (1981) Empirical relationships between phytoplankton and zooplankton biomass in lakes. Canadian Journal of Fisheries and Aquatic Sciences, 38, 458-463.

McCauley E. \& Murdoch W.W. (1987) Cyclic and stable populations: plankton as paradigm. The American Naturalist, 129, 91-121.

(c) 2012 Blackwell Publishing Ltd, Freshwater Biology, 57, 654-665 
Mehner T., Hüulsmann S., Worischka S., Plewa M. \& Benndorf J. (1998) Is the midsummer decline of Daphnia really induced by age-0 fish predation? Comparison of fish consumption and Daphnia mortality and life history parameters in a biomanipulated reservoir. Journal of Plankton Research, 20, 1797-1811.

Mills E.L. \& Forney J.L. (1981) Energetics, food consumption, and growth of young yellow perch in Oneida Lake, New York. Transactions of the American Fisheries Society, 110, 479-488.

Mills E.L. \& Forney J.L. (1983) Impact on Daphnia pulex of predation by young yellow perch in Oneida Lake, New York. Transactions of the American Fisheries Society, 112, 151-161.

Mills E.L., Sherman R. \& Robson D.S. (1989) Effect of zooplankton abundance and body size on growth of age-0 yellow perch (Perca flavescens) in Oneida Lake, New York, 1975-86. Canadian Journal of Fisheries and Aquatic Sciences, 46, 880-886.

Ohashi K., Leslie A. \& Thomson J.D. (2008) Trapline foraging by bumble bees: V. Effects of experience and priority on competitive performance. Behavioral Ecology, 19, 936-948.

Partridge D.G. \& Devries D.R. (1999) Regulation of growth and mortality in larval bluegills: implications for juvenile recruitment. Transactions of the American Fisheries Society, 128, 625-638.

Rabeni C.F. (1996) Invertebrates. In: Fisheries Techniques, 2nd edn (Eds B.R. Murphy \& D.W. Willis), pp. 335-352. American Fisheries Society, Bethesda, MD.

Rose K.A., Rutherford E.S., Mcdermot D.S., Forney J.L. \& Mills E.L. (1999) Individual-based model of yellow perch and walleye populations in Oneida Lake. Ecological Monographs, 69, 127-154.

Santucci V.J. \& Wahl D.H. (2003) The effects of growth, predation, and first-winter mortality on recruitment of bluegill cohorts. Transactions of the American Fisheries Society, 132, 346-360.

SAS Institute Inc. (2003) SAS Online Doc ${ }^{\circledR}$ Version 9. SAS Institute Inc, Cary, NC.

Stevens M.H.H. (2009) A Primer of Ecology with R. SpringerVerlag, Berlin.
Taubert B.D. \& Coble D.W. (1977) Daily rings in otoliths of three species of Lepomis and Tilapia mossambica. Journal of the Fisheries Research Board of Canada, 34, 332-340.

Threlkeld S.T. (1979) The midsummer dynamics of two Daphnia species in Wintergreen Lake, Michigan. Ecology, 60, 165-179.

Threlkeld S.T. (1985) Resource variation and the initiation of midsummer declines of cladoceran populations. Archiv für Hydrobiologie Beiheft Ergebnisse der Limnologie, 21, 333340 .

Vijverberg J., Boersma M., van Densen W.L.T., Hoogenboezem W., Lammens E.H.R.R. \& Mooij W.M. (1990) Seasonal variation in the interactions between piscivorous fish, planktivorous fish and zooplankton in a shallow eutrophic lake. Hydrobiologia, 207, 279-286.

Werner E.E. \& Hall D.J. (1974) Optimal foraging and the size selection of prey by the bluegill sunfish (Lepomis Macrochirus). Ecology, 55, 1042-1052.

Whiteside M.C. (1988) $0+$ fish as a major factors affecting abundance patterns of littoral zooplankton. Verhandlungen der Internationalen Vereinigung für theoretische und angewandte Limnologie, 23, 1710-1714.

Wilbur H.M. \& Alford R.A. (1985) Priority effects in experimental pond communities: responses of Hyla to Bufo and Rana. Ecology, 66, 1106-1114.

Wright J.C. (1965) The population dynamics and production of Daphnia in Canyon Ferry Reservoir, Montana. Limnology and Oceanography, 10, 583-590.

Wu L. \& Culver D.A. (1992) Ontogenetic diet shift in Lake Erie age-0 yellow perch (Perca flavescens): a size-related response to zooplankton density. Canadian Journal of Fisheries and Aquatic Sciences, 49, 1932-1937.

Wu L. \& Culver D.A. (1994) Daphnia population dynamics in western Lake Erie: regulation by food limitation and yellow perch predation. Journal of Great Lakes Research, 20, 537-545.

(Manuscript accepted 5 December 2011) 